\title{
VALUING APPLES: FROM THE MYSTIC APPLE TO THE DIGITAL APPLES OF THE 21st CENTURY
}

\author{
Nilüfer Pembecioğlu' ${ }^{1 i}$, \\ Nebahat Akgün Çomak ${ }^{2}$ \\ IIstanbul University, \\ Turkey \\ ${ }^{2}$ Galatasaray University, \\ Turkey
}

\begin{abstract}
:
Apple is one of the first pieces of food mentioned in the earliest stories and books of mankind and different values were attributed to apple throughout the whole history. Various societies contributed to the appreciation of it placing it in their lullabies or fairy tales as well as in their daily communication and diet. Even if it seems to be so common, humble, and accessible, the lack of it is also interpreted in different ways. Yet, nowadays, it became one of the main foods of the 21st century as well. Following a quantitative and descriptive methodology and analyzing the values attributed to Apple, this paper provides a glimpse of its history and aims to analyze the 'Apple' case in Turkey regarding it not only as a 'mystic' product affecting the whole humanity but also as an agricultural product to be paid attention with the new trends in food processing in its developing aspects. Whereas the agricultural people spend more time and energy in producing better crops all around the world, the apple case in Turkey puts a shade on modernity placing apple growers away from sustainability, innovation, and productivity. Dwelling on the media coverage of the past few years regarding the apple as a content, the paper aims to introduce the main value of the apple as a product of agriculture and handles the problem of what to do in the case of apple production in its modern sense. Field research is enriched as to provide qualitative reports based on the focus group discussions and interviews with the apple producers and decision-makers as to put forward how apple is priced or degraded. In conclusion, it provides a needs analysis format, a systematic approach to the problem as a process of identifying and evaluating the apple case. As the results put forward, growing apples require valuing them. It also requires betterestablished facts, better-trained people, and concentrating more on the specific needs of employees, customers, suppliers, etc. These needs are often referred to as "gaps," or the difference between what is currently done and what should be performed. So, re-valuing apples requires to bridge the gap between the mystic apples and the digital apples of the 21st century. Today's farmers, should become a part of the network, enrich their
\end{abstract}

i Correspondence: email niluferpembecioglu@gmail.com 
cultivation methodology and innovation capacities as to reach to precision agriculture substructure and techniques to be able to become a part of the smart agriculture. Otherwise, they keep on just swallowing the mud of the field or consuming the fake news instead of reality.

JEL: O13; Q10; Q12; Q13; Q15

Keywords: apple, smart agriculture, precision agriculture, branding, media literacy of farmers, growing apples

\section{Introduction}

Apples are the most interesting, mystic and sacred, valued items from the very beginning of human history. Not only the mentions of the holy books carry it up to the level of this kind of popularism but also the quotations of the famous people praising the apples.

"An apple a day keeps the doctor away" said Benjamin Franklin associating it with health. To Stephen Colbert, "An apple a day keeps anyone away if you throw it hard enough". "Millions saw the apple fall but Newton was the one who asked why" puts forward Bernard Baruch associating it with inspiration and creativity. To Henry David Thoreau, the apple is the noblest of fruits. Martin Luther takes the apple as the symbol of faith and hope "Even if I knew that tomorrow the world would go to pieces, I would still plant my apple tree". And Henry David Thoreau refers to the apple as the noblest of fruits. In many different ways, the concept of apple is associated with health, effort, divinity, modesty, as well as relationships and experience. Mostly known as the "forbidden fruit" apple is frequently referred to. As Mark Twain stated, "Adam did not want the apple for the apple's sake; he wanted it because it was forbidden".

According to the Crystal Apple Awarder, the reason why it is the Crystal Apple Award lies in the fact that the apple also has an association with the biblical tree of knowledge and thus, makes an excellent, lasting symbol with which to honour excellence in the education or health care fields. As for the gifts, it is easy to find silver and gold objects in the shape of an apple signifying the importance attributed to the person. These could be in the form of house decoration objects or jewellery made of precious stones. There are also perfume bottles, watches, terrariums in the form of apples. Apple in the sugar-coated apple form is the best gift for the kids.

The word "apple" also takes place in many idiomatic expressions such as to upset the apple-cart or to trade off the orchard for an apple. NY is associated with the Big Apple and the expression "as American as apple pie" is very common in the discourse. Comparing apples and oranges expresses something impossible and the use of the word 'apple' in "One bad apple spoils the whole bunch" refers to unworthy people whereas "The apple of my eye" refers to the worthy one. The expression 'Apple polisher' refers to toady people.

Apart from the daily language or colloquial usage, the concept, image, icon, and symbol of apple could be seen in any narrative, in fairy tales, legends, epics, myths, novels, poems, patterns, advertisements, posters, movies, poems, folk songs and beliefs 
as a means of communication. Even if many of the symbols resemble each other, in different countries or regions, being far apart from each other, in different times and in different cultures, each apple symbol covers the core meaning of its own surroundings and transmits it to the next generations and other cultures. For example, the bitten apple might refer to the stories in the holy book, the first sin, or the out of the box thinking styles or might refer to a mature, experienced, deciphered character.

To Memon (2014) apple is a symbol of health. As mentioned in Çolak and Özoğul (2020) apple is grown more than other fruits in the world. Recently, raising awareness in the community about consuming food rich in antioxidants is crucial for human health. As Khan et al (2017) put it, apple is a worldwide fruit grown and consumed anywhere. Apple is a highly nutritive fruit having necessary food elements such as carbohydrates $14.9 \%$ sugar $11 \%$, fat $0.4 \%$, protein $0.3 \%$, and in a balanced condition vitamins A, B \& C. After citrus and banana, it positions third in consumption and is approximately available in every season.

Even if Maslov argues that the physical needs of the person such as hunger might be satisfied with an apple, the concept seems to be covering almost all the other stratifications of the pyramid such as representing trust, when safety is concerned or regarding expressions like 'sharing an apple', 'half of an apple', 'apple of my eye' when love and belonging is concerned. Having your own apple tree might be considered as esteem and the crystal apple awards could be the symbol of self-actualization.

Turkey is one of the most important countries in the world apple production. Apple is a plant that grows in Turkey. It originates in West Asia and has spread to European countries from there. This fruit, which can be grown in any region with a temperate climate, is resistant to -30 degrees cold. Mostly, apples are produced in Isparta in our country.

Making up an apple orchard is a costly one requiring four years of planting and pre-development costs. The soil must be analysed, and then comes the planting plan dwelling more on the purpose of the orchard which also is used in the decision-making process of the cultural methods such as grass mulch plot or cover crop one. The bulky amount of the costs lies in the compiling costs ranging from the items, man and team labour, to trees and planting, hand labour, pruning and disposal of brush and tree guards, etc. Later on, mulch, cover crop seed, spraying, and making use of fertilizers would be counted. Even if there seems to be not too much to bother about the interest and taxes, an accountant would be required to keep track. Throughout the season, the thinning of the flowers and buds, picking the apples, and hauling apples to storage would also be requiring an extra budget. Sometimes, the farmers are only content with that part but if you're one of those farmers who would like to sell your own product on your own, there should be some extra budget to cover the rentals on crates and small tools such as pruning shears, saws, ladders, hoes, thinning shears, forks, picking baskets, and picking bags. Then, you have to bear the costs of grading and supervision as well as package and storage. One of the most important facts is that $10 \%$ of the apple trees might need to be replaced during the 15-years period. The product amount might also be changing. Depending upon the type of apples, a single tree could yield around $150 \mathrm{~kg}$ apples a year. 
The law of diminishing marginal returns is a theory in economics that predicts that after some optimal level of capacity is reached, adding an additional factor of production will actually result in smaller increases in output. Yet, budgeting apples could be a high one regarding the land cost, water rights, trees, pre-productive costs, it would be very easy to exceed $\$ 50,000$ an acre. Which brings us back to the main question, why we are growing apples.

Chatzopoulos, et al (2020) state that agroclimatic extremes can be seen as typical supply shifters that, on a par with economic and structural drivers, distort supply, demand, trade, and induce price variability. Economic simulation models typically operate under the assumption of 'normal' growing conditions, contain no explicit parameterization of climatic anomalies on the supply side, and confound multifarious sources of yield fluctuation in harvest-failure scenarios.

Zhao et al. (2019) cite Shi (2010) handling the apple issue from the point of application of the cobweb model, analyses the characteristics of Apple consumption in terms of total consumption and consumption level, and the elasticity coefficient of Apple demand by using of demand elasticity formula. Such fluctuations are encountered in agricultural goods markets where the time difference between the production decision and the production of the product is large. Changes in demand may also occur during this elapsed time period. Thus, considering the first seeding of an apple tree, the time, effort, and budget spend on it for at least five years without and fruits, it is reasonable to have large fluctuations occurring between the decision made for the product, the product quantity, and prices from one period to the next.

The apple prices change a lot between the main source and the consumer: In Isparta, a kg of apples in an orchard is 0.50 yet it turns to be $2.5 \mathrm{TL}$ in the market in Istanbul. The parameters affecting the apple prices might be listed as follows:

Table 1: The Price of Apple from the Field to the Consumer

\begin{tabular}{|l|c|}
\hline Place & Price (TL) \\
\hline In orchard & $0.50 \mathrm{TL}$ \\
\hline Picking & $0.20-0.30 \mathrm{TL}$ \\
\hline Basket - Packing material & $0.15 \mathrm{TL}$ \\
\hline Transportation (Bursa) & $0.15 \mathrm{TL}$ \\
\hline Transportation (İstanbul) & $0.20 \mathrm{TL}$ \\
\hline Workmanship & $0.20 \mathrm{TL}$ \\
\hline Wholesale Market Cost & $0.20-0.25 \mathrm{TL}$ \\
\hline From Wholesale to Marketplace & $50 \%$ \\
\hline Cost of the Shopkeeper & $8 \%+\mathrm{VAT}$ \\
\hline Aisle rental & $5-10 \%$ \\
\hline Loss rate & $10 \%$ \\
\hline
\end{tabular}

If only the Product Tracking Model of the Ministry of Commerce could be functional, how much the product comes out of the manufacturer and how much the market adds could be seen transparently. This system has already been set up but seems not to be operating properly at the moment. When the system functions properly, if the product prices are exorbitantly raised, these instances can be intervened immediately. By looking 
at the barcode of the product, it is possible to track where the product has been produced, bought. The difference between real price and selling price could easily be noticed as well as the price differences of direct raw materials and supplies.

\section{Materials and Methods (design/methodology/approach)}

The paper focuses on the Apple case in different ways, putting it into the focus through social, cultural, and economic perspectives. It follows a quantitative and descriptive methodology as to refer back to the values attributed to the concept of apple. Again, a quantitative methodology is applied when the media coverage is analyzed to provide further data. TUIK statistics were followed for the figures and numbers regarding the import and export rates. The qualitative data is designed regarding the field work, having interviews and questionnaires with the real workers of the fields and the specialists of the sector.

The purpose of the paper is to pave the way and raise awareness for smart agriculture and to provide the Apple case as an example. The ordinary apple is digitalized as a metaphor for the betterment of energy and dedication. The time devoted and the amount spent on growing the apple it should meet the price, yet, this could only be possible with the digitalization of the farmers, apple growers as well. In short, the paper emphasizes the importance of media literacy of the farmers including digital literacy to be prepared for the smart agriculture and precision agriculture of the near future. If they really would like to work regarding the production on demand structure, they should follow the modern techniques and methodology of growing apples.

\section{Findings and Discussion}

The data collected through the media coverage proves that the implementation of the smart agriculture techniques or betterment of the crops do not work much in Turkey regarding Apple production. Different types of apples are produced in the country and each year seems to be better than ever, yet the media stories still prove that there is no real entrepreneurship or innovation in the field of apple growing. There seems to be no hope for new brands or geographical indications within the last decades. Thus, the field workers need a training and methodology to keep them updated about the facts regarding their sector.

\subsection{News Coverage}

According to the news dated 09.12.2010, with the increase of dwarf apple orchards that produce about 2 times more product than normal apple production in Ereğli district of Konya, the cultivation areas reached 15 thousand decares and the production reached 250 thousand tons (https://www.hurriyet.com.tr/ekonomi/bodur-elma-uretimindebuyuk-artis-16489399).

The news on 23.09.2020 states that the apples can last 5 days in the fridge and the apples you peeled will no longer change color 
(https://www.hurriyet.com.tr/lezizz/dolapta-5-gun-dayanabiliyor-soydugunuz-elmalarartik-renk-degistirmeyecek-41618911).

According to news dated 09.12.2010, producing one-fourth of the whole apple production of Turkey, Isparta will be proud of having several big apple sculptures throughout the city (https://www.hurriyet.com.tr/ispartaya-kiraz-ve-elma-heykelleri$\underline{40298664)}$.

In the news dated 11.09.2020, it is emphasized that farmers have learned about the fight against climate change and drought, and it is stated that it is aimed to spread low carbon technologies in order to increase the profitability of agricult ure, land degradation, climate change, conservation of biological diversity (https://www.hurriyet.com.tr/ekonomi/ciftciler-iklim-degisikligi-ve-kurakliklamucadeleyi-ogreniyor-41608821).

To solve these problems, application lands were selected in 39 locations in 7 districts in the region, drip irrigation systems were installed to show the principles and benefits of programmed irrigation on corn, sugar beet, and apple, 13 of them were maize, 15 of them sugar beet and 11 of them apple orchards. It is stated that planned irrigation techniques are applied. Underground drip irrigation technique is used in apple orchards as an advanced technology in the region.

In the news dated 04.09.2020, it is mentioned that there are 8000 kinds of apples in the world and the unknown mythological characteristics of the apple are explained (https://www.hurriyet.com.tr/ekstra-ozel/lezzet/mitolojide-de-yeri-var-gunumuzsofrasinda-da-elmanin-hic-bilmediginiz-ozellikleri-41602971).

In the news dated 07.09.2020, it is mentioned that fruits such as apples can also be beneficial during the menopause process (https://www.hurriyet.com.tr/mahmure/menopozda-saglikli-beslenme-tuyolari$\underline{41605315})$.

In the news dated 31.08.2020, it is stated that apple is a portion of food that improves sleep quality and carries tryptophan amino acid (https://www.hurriyet.com.tr/lezizz/kaliteli-uykunun-yolu-da-mutfaktan-geciyor41599606).

News dated 17.08.2020 reflects that according to the data of the Western Mediterranean Exporters Association (MPWS), the export of fresh vegetables and fruits increased during the pandemic period compared to the same period of the previous year. Exports to 73 countries seem to have increased between 18.41 percent and 55.78 percent compared to the same period last year (https://www.hurriyet.com.tr/ekonomi/yas-sebzeve-meyve-ihracatinda-pandemi-surecinde-artis-41588840).

News dated 17.08.2020: according to the data of the Western Mediterranean Exporters Association (MPWS), the export of fresh vegetables and fruits increased during the pandemic period compared to the same period of the previous year. Exports to 73 countries seem to have increased between 18.41 percent and 55.78 percent compared to the same period last year. 35 kinds of fresh vegetables and fruit including apples were sent to 73 countries, mainly Germany, Russia, Romania, Ukraine, and Bulgaria. 
In the news dated 20.07.2020, it is mentioned how the historical artifact with apple tree motifs seized in Amasya was saved from thieves (https://www.hurriyet.com.tr/kelebek/keyif/kacak-kazida-ortaya-cikan-1800-yillikelma-mozaigi-sergileniyor-41568471).

In the news dated 23.05.2010, it is stated that "apple chips", which have been produced at the Elmataş Factory in Isparta since 1991 but only exported, will soon be offered to the domestic market (https://www.hurriyet.com.tr/ekonomi/elma-cipsi-icpiyasada-14811254). Elmataş Technical Manager Süleyman Kızılelma says that 30 tons of apple chips are produced in a completely natural environment without any additives, and when sales and demands are considered, it is understood that more production will be made next season.

In the news dated 28.03.2013, it is mentioned that the export of pear to the Middle East countries through Iran and Syria in the district of Gürsu in Bursa, following the events in Syria, was completely stopped (https://www.hurriyet.com.tr/ekonomi/deveciarmutlari-depolarda-kaldi-fiyatlar-dipte-22917916). The news emphasizes that around 20 thousand tons of products, including 12 thousand tons of Amelanchier pears, along with apples and quinces, remain in the warehouses and should be consumed within 20 days.

An article dated 25.02.2014 puts forward that Turkey's apple, quince, orange, cherry, plum, peach production is stated that the decrease (https://www.hurriyet.com.tr/ekonomi/tarim/bugday-ve-kayisi-uzdu-cay-ve-uzumguldurdu-27840323). The apple production amount decreased from 3 million 128 thousand 450 tons in the previous year to 2 million 480 thousand 444 tons in 2014 with a decrease of $20.7 \%$.

In the news dated 25.02.2014, the research conducted by the Istanbul Metropolitan Municipality (IMM) State Directorate with the participation of 8 thousand people are mentioned and the top 5 favourite winter fruits are questioned (https://www.hurriyet.com.tr/ekonomi/ispanakla-portakal-kis-in-en-sevilen-i-ciktiayva-ile-karalahana-dipte-kaldi-19202378). 35\% of the respondents stated that they like orange, $26.7 \%$ apple, $17.2 \%$ mandarin, $3.8 \%$ pomegranate and $2.9 \%$ banana. However, apples are easy to find in any season. According to Engindeniz \& Engindeniz (2003) peaches are considered to be the "Queen" of fruits and second only to apples in popularity as deciduous tree fruit, because of their fine flavour and many uses.

In the news dated 28.10.2009, fruit juice producers state that other countries encourage fruit production, while Turkey causes some stagnation due to the problems of unconscious agricultural policies and wrong fruit production (https://www.hurriyet.com.tr/bilincsiz-tarim-politikalari-meyve-suyu-sektorune-zararveriyor-12794885). And they complain that they could not find enough raw materials and cause the sector to shrink.

In the news dated 09.10.2013 Rowan Burrough is introduced as an eco-warrior who has made his home in an apple tree to prevent developers from chopping it down. He has spent most of the week in the 150-year-old tree, in the heart of Cider with Rosie country in Gloucestershire (https:/www.dailymail.co.uk/news/article-2449221/Stroudapple-tree-Eco-warrior-Rowan-Burrough-living-tree-homes-built.html). 
In the news dated 19.03.2011, an organization company called Speaking Roses is introduced and it is mentioned that lovers in Turkey send each other mostly red roses and green apples. The director of the company states that a client asked to add a note as "That's how Eve fooled Adam" (https://www.hurriyet.com.tr/kelebek/havva-da-adem-iboyle-kandirmisti-diye-sevgilisine-elma-gonderen-var-17313132).

The news dated 09.15.2014 states that up to recent years producing fruit juice from local fruits grown in Turkey could help the fruit juice market only $\% 2$ percent a year (https://www.hurriyet.com.tr/ekonomi/yerel-meyvenin-suyu-cikti-27199849). However, it is noted that the fruit juice market grew by 12 percent in the first quarter of 2014.

The news dated 10.28.2012 states that the Ministry of Agriculture and Forestry is happy with the supporting policies for organic farming increases the production by $116 \%$ (https://www.hurriyet.com.tr/uretim-yuzde-116-artti-21791926). In 2010 it was 1 million 343 thousand tons and in 2011 it was 2 million 905 thousand. With the focus on organic agriculture, once the total area of 90 thousand hectares increased to 615 thousand hectares in 2011. In the same period, the number of organic farmers increased from 12 thousand to 42 thousand. Fruit production, with 190 thousand tons of organic products took the first place, followed by wheat production with 92 thousand tons and vegetable production with 29 thousand tons. In exports, the first three products consisted of olives, apples, and cotton. In Turkey, 15 million 500 thousand dollars was made in 2011 through the exports of organic agricultural products.

According to the news dated 14.07.2017, 71-year-old Melahat Peker, who lives alone in Yalvaç District of Isparta, reacted to the cutting of 5 apple and 1 mulberry saplings by the municipality after the neighbours' complaints (https://www.hurriyet.com.tr/kesilen-agacini-omuzladi-neden-kestiniz-diye-40519706).

According to another news dated 08.10.2015 in Isparta, 646 thousand 266 tons of apples were produced in 223 thousand 648 hectares in 2014 and thus the city took the first place in the total apple production in Turkey (https://www.hurriyet.com.tr/ispartada-elma-hasadi-basladi-37177858). According to the news dated 11.10.2012, quality apples cannot find a suitable market. Apple production seems to be possible in almost every region of Turkey. In 2002, the products were only 2.2 million tons and it reached 2.8 million tons in 2011 with an increase of approximately 27 percent. Of the 69.6 million tons of apple production of the whole world, Turkey has about $4 \%$ share and ranks in third place after China and the US (https://www.hurriyet.com.tr/kaliteli-elma-pazarbulamiyor-21666972). However, in 2016 Turkey covers 3\% of the whole production of apples reaching up to 85.2 million tons. In 2017 the world production decreases to 83.1 million tons whereas Turkey covers $4 \%$ of it whereas the amount of apple production increased by about 3,6\% in the country (https://en.wikipedia.org/wiki/List of countries by apple production).

In the news dated 21.10.2009, apples are counted among foods that protect against cancer and fruits containing flavonoids (https://www.hurriyet.com.tr/kelebek/istekanserden-koruyan-yiyecekler-12740022). And in the news dated 22.06.2010, it is mentioned that apple cider vinegar balances the cholesterol deteriorated in menopause and diabetes (https://www.hurriyet.com.tr/kelebek/elma-sirkesi-mucizesi-14982987). 


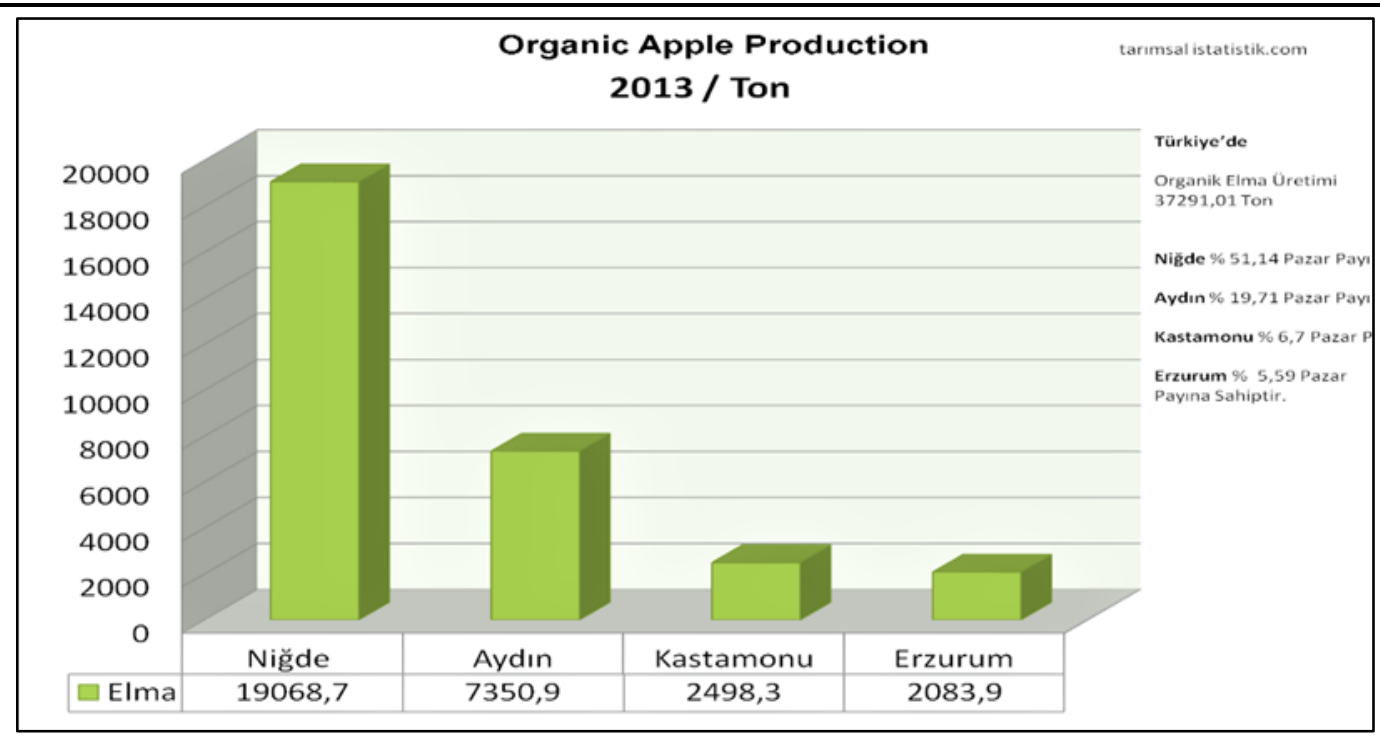

Figure 1: Organic Apple Production in Turkey

According to news dated 10.04.2016, it is also stated that 50 thousand tons of apples are waiting to be sold in cold storage in Karaman (https://www.hurriyet.com.tr/ekonomi/50-bin-ton-elma-depoda-kaldi-40085193).

In another news dated 04.02.2017, apples placed in cold storage in Korkuteli, another town famous for its apples, are exported to the Middle East and Arab countries after Istanbul, Ankara, Izmir, and Antalya (https://www.hurriyet.com.tr/korkutelideelma-ihracati-40355797). It is mentioned in the presence of a total of approximately 1.5 million tons of storage capacity in Turkey scattered all around the country (Cennet \& Karaçayır, 2009).

In the news dated 10.03.2015, it is mentioned that a businessman from Çanakkale provided 40 tons of apples as food aid to the Syrian refugees living in tent cities in Gaziantep and Kilis (https://www.hurriyet.com.tr/ekonomi/hem-siginmacilari-hemureticileri-sevindiren-yardim-28415856).

In the news dated 17.04.2014, it is stated that excessive pesticide use in fruit growing is risky (https://www.hurriyet.com.tr/elmayi-bu-sistem-koruyacak-26224543). It is emphasized that there are three forecasting and early warning systems in Ankara and, thanks to these systems, hourly averages of data such as air temperature, humidity, rainfall and leaf wetness in the region can be recorded. Thus, apple growers can determine the best time to combat disease and harmful factors.

In the news dated 30.10.2019 (https:/www.hurriyet.com.tr/lezizz/galeri-ici-disikirmizi-elmaya-cografi-isaret-tescili-41340564), the "red apple both inside and outside", which has a history of about 200 years and grown as an endemic species in Posof district of Ardahan, was registered by the Turkish Patent Institute with a geographical indication. Another geographical indication is registered for the 'long apples' as they call it growing only in Kars, Sarikamish, and Kağıman. These registered brands provide better visibility to apple throughout the markets (https://www.aa.com.tr/tr/turkiye/kagizman-uzun-elmasi-tescillendi/1030059). 


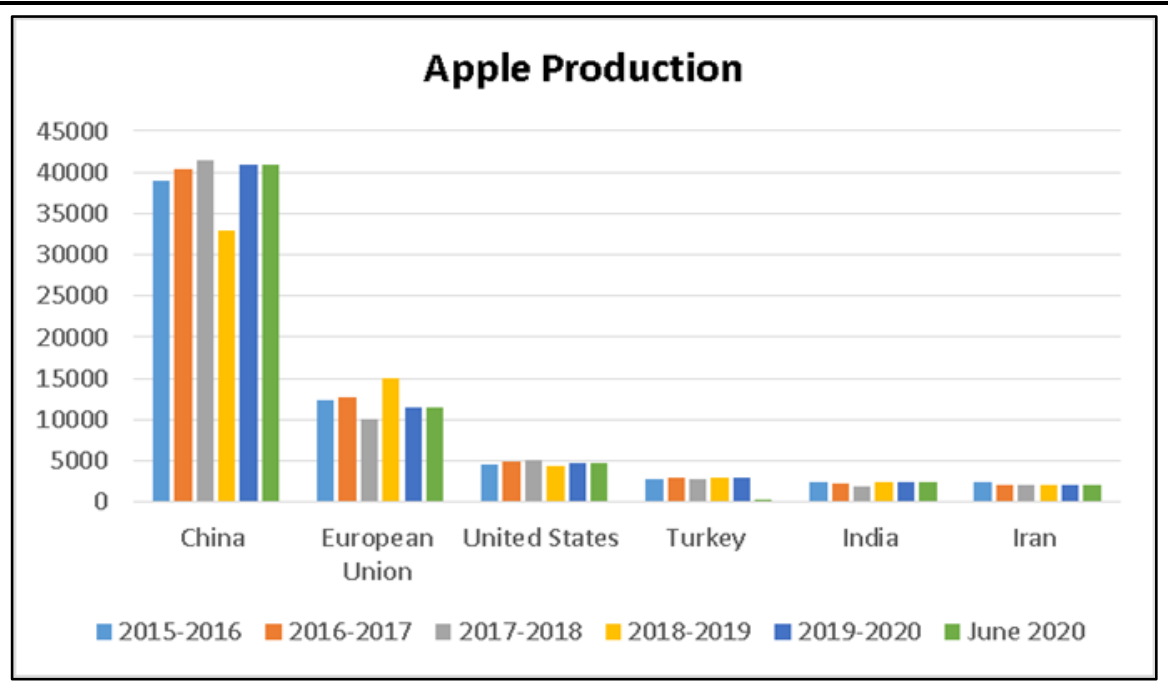

Figure 2: World Row in Apple Production

(Source: https://apps.fas.usda.gov/psdonline/circulars/fruit.pdf)

\subsection{Other Facts About Apple}

In all these news media presents a kind of blurred image of apples. The farmers growing apples were not respected and valued. The importance of apple as an export product is not recognized or represented efficiently. So, the apple does not sound or taste nice when we look at it through the news glasses or digital media. If we really want valuable apples, we need to handle the issue with great care and convince others to think and behave in the same way. Apple is in the media when there's something wrong with it.

Today, with 3 million tonnes, Turkey is in the fourth of the fresh apple production list after China, EU-27, and the USA (https://www.indexmundi.com/agriculture/?commodity=apples\&graph=production).

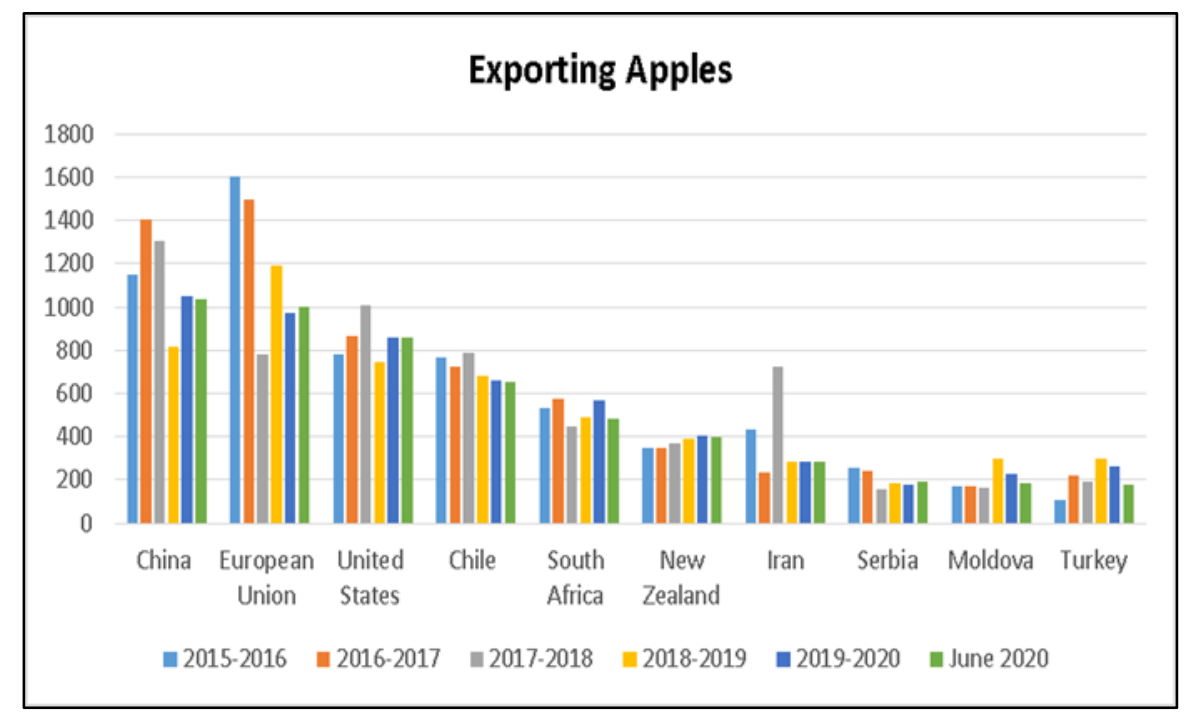

Figure 3: World Row in Apple Production

(Source: https://apps.fas.usda.gov/psdonline/circulars/fruit.pdf)

According to USDA's National Agricultural Statistics service's report dated by June 2020, Turkey's production is projected to repeat last year's record of 3.0 million tons 
as orchards experienced a second straight year of mild winter weather and good spring conditions for flowering and fruit development. Despite higher supplies, exports are expected to drop nearly 40 percent to 180,000 tons on reduced shipments to top markets Iraq and Syria during the latter half of the marketing year (https://apps.fas.usda.gov/psdonline/circulars/fruit.pdf).

Interestingly, Turkey and Iraq were the top importers of Ukrainian apples in 2018/19, despite importing almost nothing just a few years previously (https://www.fruitlogistica.com/media/fl/fl dl all/auf einen blick/European Statistics Handbook 2020.pdf). Even if we seem to be exporting too much, we also import a lot of fruits, for example, by 2018, 234 thousand tons of fresh fruit from Ukraine and 29 thousand tons from Georgia were imported.

Apples produced in Turkey can only be exported to $0.3 \%$. As a country that ranks 4th in apple production in the world, its export rate in production amount is very low (Oğuz, Karakayacı \& Kalyoncu, 2009).

\begin{tabular}{|ll|}
\hline \multicolumn{2}{|l|}{ WAPA MEMBERS } \\
1 & China \\
2 & USA (5 Members) \\
4 & Poland \\
7 & Italy \\
8 & Chile \\
9 & France \\
9 & Ukraine \\
11 & Brazil \\
14 & Argentina \\
15 & South Africa \\
21 & Germany \\
27 & New Zealand \\
28 & United Kingdom \\
35 & Australia \\
36 & Moldova \\
40 & The Netherlands \\
55 & Belgium \\
56 & Slovenia \\
57 & Croatia \\
69 & Denmark \\
\hline
\end{tabular}

Table 2: World Row in Apple Production

WAPA (The World Apple and Pear Association) is an industry body established in 2001 to provide a global forum for representatives of apple and pear producing countries (http://www.wapa-association.org/asp/page 1.asp?doc $\mathrm{id}=436$ ).

The Association harnesses the collective strength of all members' inputs to foster and enhance business opportunities for the collective benefit of both sectors. This collective will be essential to help maintain the exclusive position of apple and pears in the minds of consumers and to increase the strength of apple and pear producers on the global political agenda. It is interesting to note that it doesn't have any Turkish members (http://www.wapa-association.org/asp/page members.asp). 
"The apple market in the EU: Vol. 1: Production, areas and yields" is a report produced by EU Fruit And Vegetables Market Observatory Pip Fruit subgroup (https://ec.europa.eu/info/sites/info/files/food-farming-

fisheries/farming/documents/apples-production en.pdf) by 15 May 2020, analyzing the production capacity of the EU Member countries. Turkey is not involved in the group.

The area of apple production in the world has reached five million hectares. $45 \%$ of apple production areas are located in China. Turkey in terms of apple production area is located 5.4 Values in the world (https://www.zmo.org.tr/genel/bizden detay.php?kod=32410\&tipi=38\&sube=0).

\begin{tabular}{|l|r|r|r|}
\hline Country & \multicolumn{1}{|l}{ Area } & Amount & Productivity per Hectar \\
\hline 6 United States & 130710 & 5085000 & 38,90291485 \\
\hline 1 China & 2220430 & 41390000 & 18,64053359 \\
\hline 7 Iran & 119528 & 2097000 & 17,54400643 \\
\hline T Turkey & 175357 & 2750000 & 15,68229383 \\
\hline 2 India & 305000 & 1920000 & 6,295081967 \\
\hline
\end{tabular}

Table 3: Countries by Area, Amount and Productivity per Hectare (2017)

Turkey's apple exports exceeded 250 thousand tons in 2019. A very important part of apple exports is made to Iraq. Apple exports to Iraq in 2016 and 2017 amounted to 65\% of total apple exports. In 2019, export revenue of \$ 90 million was obtained in return for the export of 256 thousand tons of apples (https://www.zmo.org.tr/genel/bizden detay.php?kod=32410\&tipi=38\&sube=0).

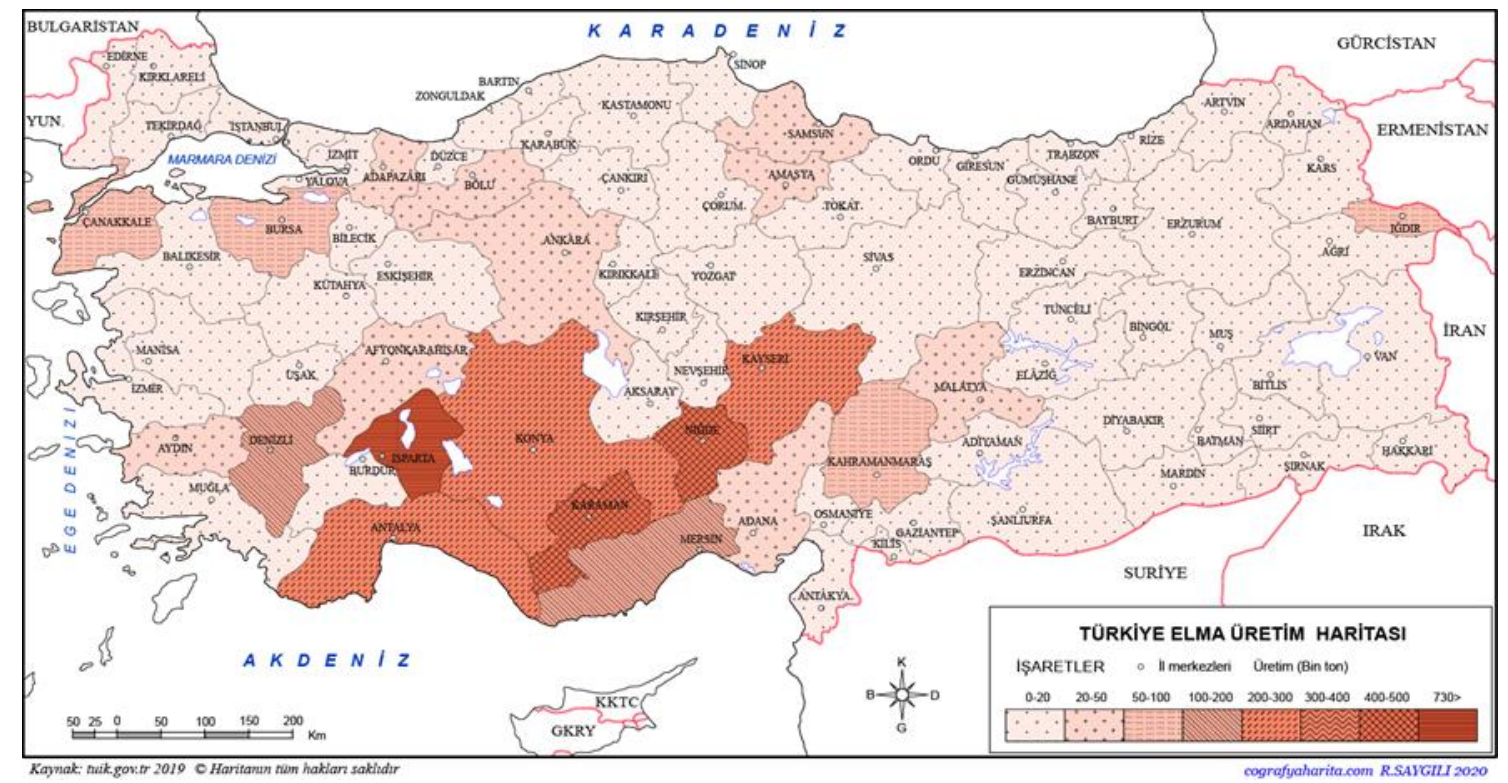

Figure 4: Map of Apple Production in Turkey

Apple, which can be grown in almost every region, ranks first among soft stone fruit types in terms of production amount. The number of apple varieties in the world is thought to exceed 10,000 . In our country, this number is about 500 . Although our country 
is one of the gene resources of apple, the number of varieties that are commercially accepted and cultivated in the world is low. Although many new apple varieties are developed every year, the number of varieties accepted in the market is not very high (https://tarimdabugun.wordpress.com/2015/12/19/turkiyede-elma-uretimi/).

Fruit cultivation is carried out in approximately $14 \%$ of the total agricultural areas of our country. Apples in the soft pome fruit group constitute 5.3\% of the total fruit areas and $0.7 \%$ of the total agricultural lands. Our country, which has an important place in apple production in the world, produces 2,480,444 tons of apples on an area of approximately 1.7 million decares.

When apple production is examined in our country as of 2000, it is seen that there is no significant change in apple cultivated areas and production amount. The growth rates experienced in apple production in the world were slightly higher than in our country. While there was a 37\% growth in the amount of apple production in the world as of 2000, there was an $18 \%$ growth in our country (https://www.mevka.org.tr/Yukleme/Uploads/Dsytc6Ix5719201754304PM.pdf).

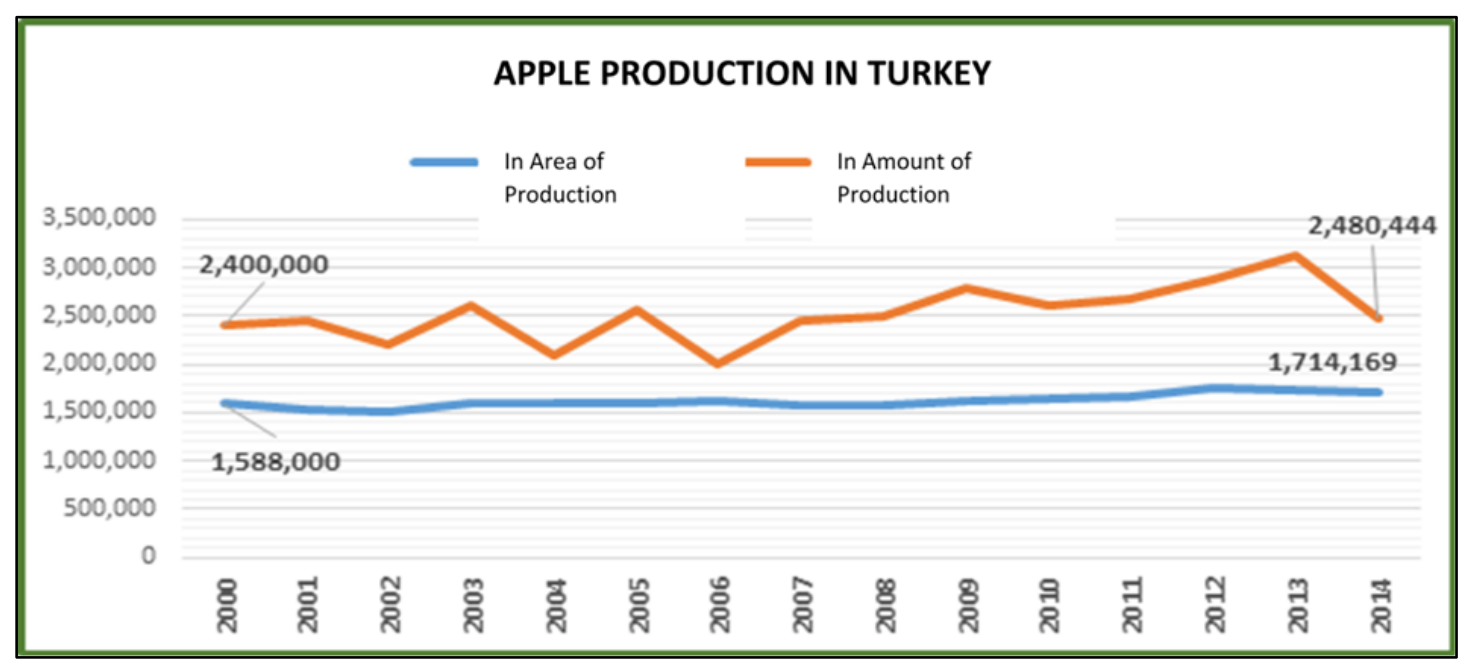

Figure 5: Apple Production in Turkey between 2000-2014

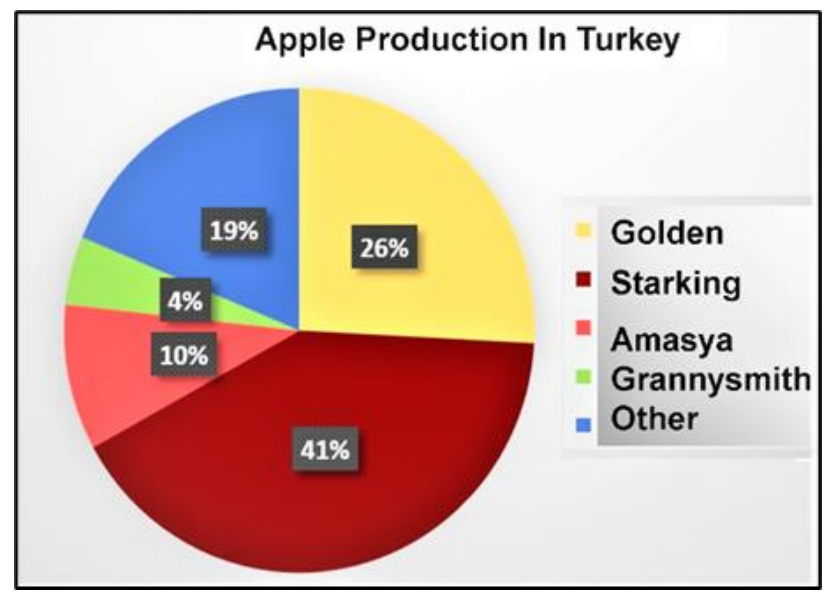

Figure 6: Type of Apple Production in Turkey 
With the announcement of August 2020 inflation data by TURKSTAT, apple ranked third among the fruits whose prices increased the most (Melon 7.49\%; Watermelon - 7.25\% and Apple - 6.58\%).

\subsection{Interpretations of the Facts \& Coverage}

There might be so many different things to be stated regarding the facts and coverage of the apple issue. There is so much news, made just for the sake of being made and these do not represent the value of the product apple. They neither value the producers, nor the customers. These newsmakers are not aware of the fact that Apple is a really valuable, precious, and promising product for Turkey. And just with a few made-up news, they might easily stymie the producers. Some of the news seems to be having some political reasonings rather than economic or agricultural. Getting deeper inside the news one may figure out that even the sincere thoughts of the farmers were used as bad news to be poured into the ears of the audience.

Bad News 1: As mentioned in Çolak and Özoğul (2020), as a result of their studies and analysis of some pomological and biochemical features of the genotypes obtained in the city of Uşak, the UO1, UH, PB, EK1, EK2 genotypes seem to be promising in terms of their fruit weight, width, and height. Yet, unfortunately, there seem to be no patenting, brand making, or marketing attempts for it.

Similar to this occasion, as mentioned in another study of Celik, Kazankaya, and Ercişli (2009), a few temperate zone fruit species such as apples, pears, apricots, and cherries dominate the fruit production in the Eastern Anatolia region in Turkey, while the other species (e.g rosehip, hawthorn, sea buckthorn, etc.) are less known. Native species grown in their natural ecosystems could be exploited as new foods, valuable natural compounds, and derivatives. No studies were conducted regarding the apples and their derivatives.

Distribution of the apples according to Dursunoglu and Ertunc (2006), proved that pome fruits, traditionally grown in Turkey, are becoming one of the main local fruit crops yet they are highly affected by Apple mosaic virus as a widespread virus infection for apples affecting $29,75 \%$ of the total samples collected from randomly selected orchards of the main pome fruit growing areas of Central Anatolia, Black sea, Mediterranean and Marmara regions of Turkey. However, to betterment took place in these areas, concluding affecting the one-fourth of the whole apple production.

Another study, (Dündar, Uygun, Özkaya, 2009) questioned the limitations of "Granny Smith Apples". Throughout the study, storage in cold store under normal atmospheric conditions for 6 months then 7 days of shelf life of 'Granny Smith' apple variety that was grown in Niğde conditions and harvested in two different harvest times were examined. Superficial scald was found as one of the important limitations of 'Granny Smith' apples after 4 months of storage. As a result, the evaluation of harvest dates showed that the 1st harvest time is more suitable for storage purposes of this cultivar, and the 'Granny Smith' apple variety was stored more successfully at $1{ }^{\circ} \mathrm{C}, 85$ 90\% RH during 6 months. 
According to Plant Production report, of the Tenth Development Plan (2014-2018), prepared by the Ministry of Development (TC Kalkınma Bakanlı̆̆1), Specialization Unit, in the competitive analysis made; regarding corn, wheat, rice, canola, apple, soybean, sugar beet, cotton, sunflower and almond products there seems to be no comparative advantage of Turkey. That means we need to develop better crops and products in order to compete with the other producers.

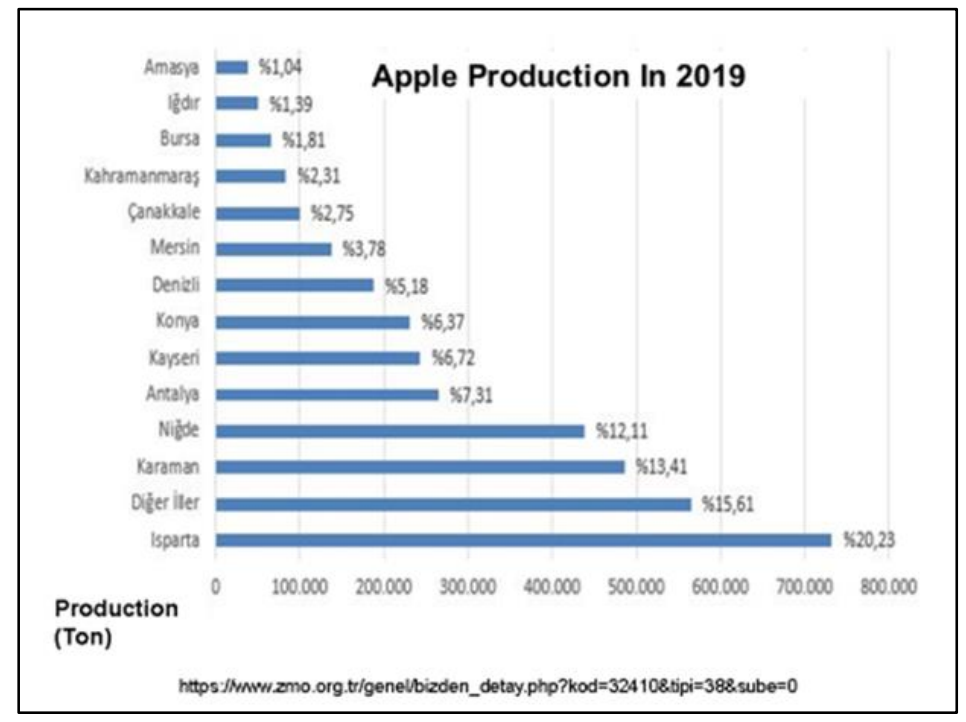

Figure 7: Apple Growing Cities in Turkey

Growing better apples could only be possible with great care and knowledge. For example, Emongor, \& Murr, (2001) state that under optimum conditions apple trees normally produce 5 to 20 more blossoms than are required to produce a commercially desired size and quality crop. Individual fruiting spurs produce 5 to 6 flowers yet support a maximum of 2 fruits. Under ideal conditions, 5-10\% of the blossoms on a tree can set to produce a full crop. If an apple tree is to maintain annual cropping, be able to support root growth, and accumulate enough reserves to withstand temperature stress in winter, a sizeable proportion of these spurs must "rest" in any given season. Excess blossoms and/or fruits should be removed to adjust the leaf-to-fruit ratio to a desirable level. Thinning can be accomplished by hand and/or chemical sprays.

Having researched on Granny Smith apples (Malus Domestica Borkh.) Erkan et al. (2004) claim that apples harvested at optimal harvest time and stored in appropriate humidity can stand for 9 months. Interviewing 129 apple farmers alongside Isparta, Karaman, and Niğde area Gül (2006) pointed out that appropriate soil tests should be made to determine fertilizer requirements of the soils, and the most significant factor affecting efficiency was found to be the size of the total apple orchard.

Thus, it seems that at the age of the 21st century, we still have communication problems and as stated in the commission report (https://ec.europa.eu/research/innovation-union/pdf/innovation-unioncommunication en.pdf). Education and research, as well as innovation, are the most important factors and they work on a complementary basis. Thus, researchers and 
innovators must be able to work and cooperate across the country and EU on a digital platform, questioning, analyzing, and producing altogether. There might be some kind of counselling or distance education to raise awareness and to implement the new methodology. Or just sessions to share expectations and experiences. Excellence might be aimed as a guiding principle instead of leaving things in their own nature and waiting for the apples to grow on their own. Sometimes it is easy to see how the concept of 'organic' could be misunderstood. Organic agriculture means doing nothing for the crops and products.

There seems to be more need for innovations out of the research. Thus, cooperation between and among the different steps and units of production should be maintained and enhanced. The farmers, innovators, and entrepreneurs should work hand to hand to overcome the difficulties caused by the regulations and achieve the strategic use of time, budget, and labor. Farmers, unions, and markets should be represented digitally and identification is the main problem to be solved. That means gaining visibility for each crop and apple orchard to develop the market and to protect the producers. There should be no way for product returns. That means, there should be a better balance between the control-based and a trust-based system. There should always be a place not only for the top producers but for small business people providing uniqueness and adding richness to the market. There should be more products carrying geographical indications providing representation making the brands visible.

Having a market for the best products might be the easiest way but there are other problems that need to be taken care of such as storing, preserving, transporting, crop processing, developing electronic article surveillance programs, providing visibility for the product family as well. Grafting is important to achieve better products by combining the best product every year with the best product of the other year.

There should be a needs assessment for the products as well. For example, in the story of Maria Ann Smith believed to be the one growing the first Granny Smith Apples in 1868, apples were used for cooking in Australia. Later on, these green apples caught the attention of EK Wolstenholme, the Manager of the Bathurst Orchard Experiment Farm and he planted them assuming that those apples would be suited to growing at altitude in the Central West in 1912 when he bought land and planted his own trees (https://www.lithgowmercury.com.au/story/184990/the-history-of-the-granny-smithapple/).

Orchardist George Hazelwood of Kelso discovered his best Grannies grew in a white granite soil where there was a dry summer and sold apples to the American Army in 1918. It took the Granny Smith apples 50 years to achieve worldwide acclaim, to become the second most popular selling apple both in the UK and Europe. Yet, now they are not cooked but eaten fresh. Or they are cooked in a different way such as an Apple Pizza (https://www.youtube.com/watch?v=AavSPaDPjC4).

That means, creating an innovation market may take time but it really pays better than anything else. This is also very important regarding the eco-innovation, organic, and approved crops providing long-term predictability. That also means, yes, there should be standardization but there should also be some space for betterment and innovation. 
Not only tastes might change throughout time, but also the way of use styles of usage, area of utilization as well as supply and demand chains. The different characteristic qualities of the product should also be questioned rather than merely the size, color, or flavor. Demand mechanisms could be changed not only by the way of production but also by the accessibility of the product. Up to recent years, apples were sold in $\mathrm{kg}$ or pounds but now the people buy it one by one.

Thus, individualized tastes and preferences could be gaining more importance, accessibility and the transfer of the product would be more important instead of bulk imports and exports. Instead of selling apples in thousand tons perhaps mobility of smaller amounts would be more practical but requiring more digital systems, better and careful planning.

With precision agriculture technology it is possible to know precisely what is needed, where, and when (https://www.youtube.com/watch?v=581Kx8wzTMc). The technology-based supra-structure thus nurtures the producers who are also threading the infrastructure of the products. New applications in agriculture provide IoT solutions to farmers to measure a lot of different parameters to make the life of gardeners more efficient. They measure water conditions, soil conditions, environmental conditions, and even security conditions to see and allow only the people registered going into the gardens. They use the cyclic network and deployment to send that over ten minutes in order to manage at the right moment to irrigate for the governors and try to facilitate their daily tasks the whole project due in a year. They help the farmers reduce the cost of water and pumping up to $30 \%$ as well (https://www.youtube.com/watch?v=RQvyicE0ByI).

Helping the procures collecting a lot of information from different sources and in different parts of the field on things like soil nutrients the presence of pests and weeds the level of ripeness of fruits, calculating the time should be spent in the storage, etc. Supplying the producers with the weather forecasts may reveal the nutritional needs and even determining how much of a certain fertilizer should be applied with many other agronomic recommendations on time. Once applied this kind of sophisticated flow of information could also include and collect geo-referenced information. As a result, we may say that precision agriculture might be a real option for medium and small-scale producers.

\section{Conclusion}

European Union Business Economics and Innovation Research Center had a survey in 2006. The scope was the study of putting the knowledge and experience load of each profession into an analogy of a book that will make the entrepreneur successful and measuring how many pages the information would be equivalent to a book. Each book contains data in terms of technical knowledge, business knowledge, business management, experience, and moral-ethical values, etc. So, in order to be a theater box Office clerk, you need a cumulative knowledge of 1245 pages. If you want to be a greengrocer 3080 pages of registered knowledge is required. Please be careful, we tend 
to put the greengrocer and butcher into the same category, but a butcher has to be twice skilled as the greengrocer.

Within its Horizon Europe research and innovation program for the 2021 to 2027 agri-research conference they are talking about 'Innovating for the future of farming and rural communities' again they are positioning the farmers with new business models having farmer-owned brands.

Farmer knowledge is the result of farmers' own curiosity, creativity, and efforts. Ownership of self-made knowledge strengthens farmers' professional identity, pride, confidence, and willingness to farm - important in the context of a declining farming community.

Regarding all these new innovative types of farming knowledge and techniques, it seems that most of the apple growers in Turkey neither know nor search for the betterment of their crops. They usually do not follow the networks, trends, or new, industrial agriculture techniques. They do not apply the world standards, or care for their apples as to make brands of them. Whereas the other countries such as the USA, having 7 times less space than Turkey for apple production could manage to export apples 26 times more than Turkey, Turkish apple growers seem to be just following the rule of thumb. Thus, dwelling on the media coverage of apple news of the past years, this paper introduces the rate of neglect and pessimistic view among the producers, instead of following smart agriculture techniques and strategies. The paper aims to raise awareness and open up ways for innovation in the field of scientific and innovative production styles to reach precision agriculture in Turkey. According to 17.02.2020 Apple report of 2019 TMMOB - Ziraat Mühendisleri Odası the apple case in Turkey needs remedy.

Apple production in Turkey shows a significant improvement and our annual production reached four million tons. The apple production of Turkey, which was 283 thousand tons in 1961, has increased more than twelve times up to date. Isparta is the city where apple production is made the most. In Isparta, $20 \%$ of the total apple production was realized with 732 thousand tons of apple production in 2019. Yet, as Gelendost Apple, having two different types Gelendost Golden Delicious Apple and Golden Starking Delicious Apple applied for a patent in 2012. 2/3 of apple production in Turkey is growing in the provinces of Isparta, Karaman, Niğde, Antalya, Kayseri, and Konya. Approximately 1.7 million acres in Turkey are spared for apple production. Niğde, Isparta, and Karaman are the provinces standing in the first rows of the cities producing most of the crop. The most cultivated apple variety is the Starking apple. Its share in total apple production can reach $40 \%$. This might be an advantage or disadvantage. Advantage because most of the people would like to buy that kind of apple in the market. Still, it is a disadvantage because the new apple growers taking part in the market need to struggle more to become known in the market. If it were the organic apples of Niğde, the percentage would be only 1 , and the producers are known better in the market since there are only a few of them.

The number of apple trees in Turkey is about 80 million. About 15 million of these are apple trees that are not yet fruiting. So, this should motivate people to go for branding and marketing their apples even if they are not there yet. Because when the first apples 
appear, it would be too late to act. World apple production was 83 million tons in 2017 and $50 \%$ of the production is carried out by China. In terms of apple production area Turkey rates as the $5^{\text {th }}$ biggest in the world. Yet, there seem to be some other competitors around.

That means Turkey should develop strategies to concentrate more on apple production. Turkey's apple exports exceeded 250 thousand tons in 2019. A very important part of apple exports was made to Iraq. Although Turkey's apple imports may reach up to a thousand tons in some years, it was 280 tons in 2019 and 193 thousand dollars were paid in return. That seems to be a kind of warning to produce quality apples. Germany is the country that imports the most apples. In 2017, it imported apples of 680 million dollars' worth. Although we are in the top ranks in the world production of an important soft stone fruit type such as apple, due to lack of knowledge, sufficient production increase rates and export could not be achieved. Apple export in the world has approached 10 million tons. The country that exports the most apples in the world is China, which realizes $14 \%$ of total apple exports. World apple exports have a size of 8 million dollars. When apple productivity is compared with apple plantations, it is nice to see that productivity increases from 9.8 per hectare in 1998 to 13.3 in 2006 . Turkey seems to be just catching the scale. Even if the apple plantations seem to be increasing compared to 2006 to 2017, regarding the number of apples produced the productivity rate seems to be decreasing.

Table 3: The price of apple from the field to the consumer

\begin{tabular}{|l|c|c|}
\hline Turkey & $\mathbf{2 0 0 6}$ & $\mathbf{2 0 1 7}$ \\
\hline Area & 110000 & 175357 \\
\hline Amount & 2550000 & 2750000 \\
\hline Productivity & 23,2 & 17,5 \\
\hline
\end{tabular}

\begin{tabular}{|l|c|c|c|}
\hline Country & Area & Amount & Productivity per Hectare \\
\hline 6 United States & 130710 & 5085000 & 38,90291485 \\
\hline 1 China & 2220430 & 41390000 & 18,64053359 \\
\hline 7 Iran & 119528 & 2097000 & 17,54400643 \\
\hline 5 Turkey & $\mathbf{1 7 5 3 5 7}$ & $\mathbf{2 7 5 0 0 0 0}$ & $\mathbf{1 5 , 6 8 2 2 9 3 8 3}$ \\
\hline 2 India & 305000 & 1920000 & 6,295081967 \\
\hline
\end{tabular}

Instead of the traditional apple orchards of the past, today, we may talk about the existence of large enterprises as a growing sector. In recent years, apple production has turned to be large enterprises where intensive production is carried out instead of traditional methods, yet, commercial purpose and mass production have come to the fore. With the development of the subsidiary industry, apple today is not only fresh fruit, but it has also become the source of other food sectors. There might be some suggestions. (https://www.zmo.org.tr/genel/bizden detay.php?kod=32410\&tipi=38\&sube=0) 


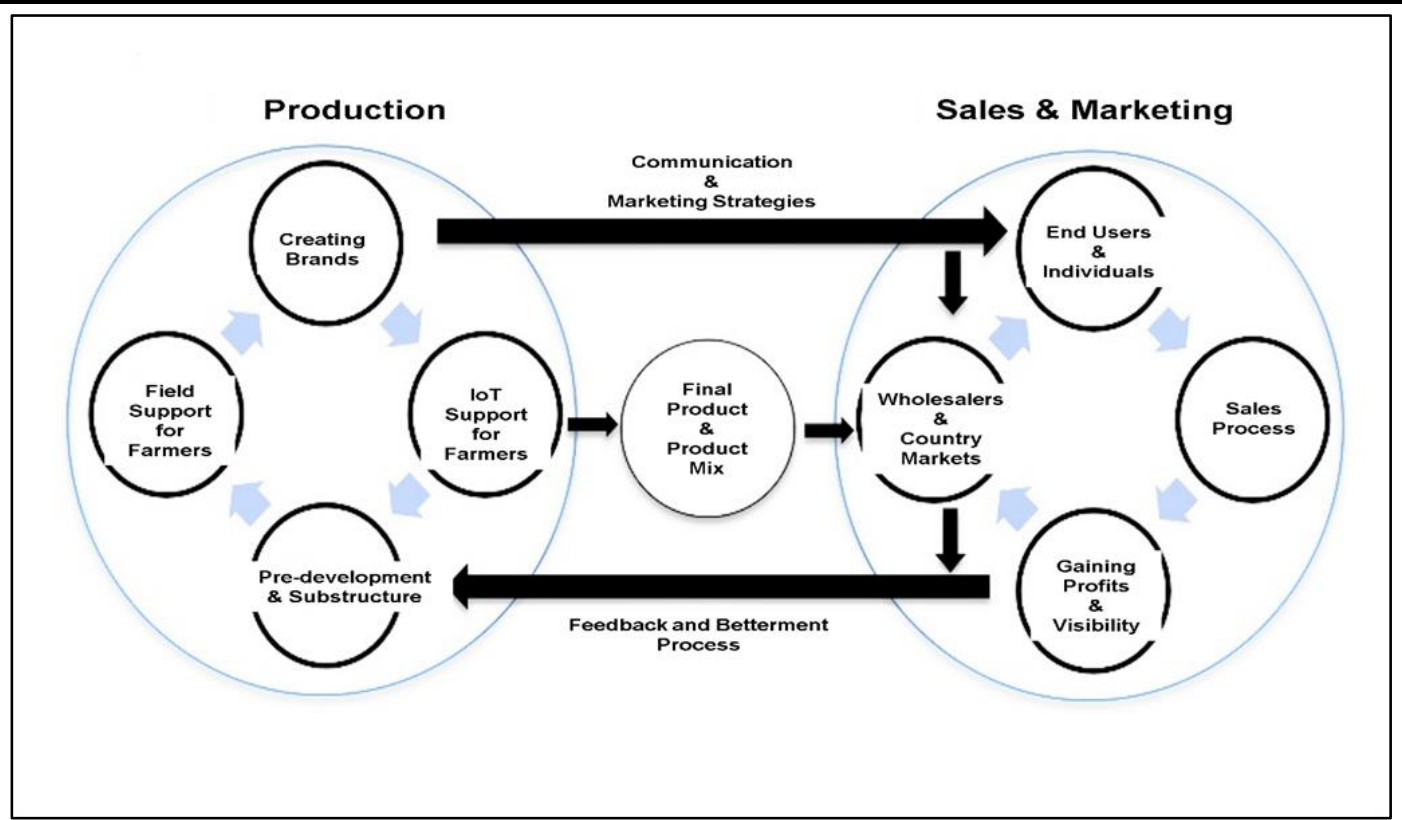

Figure 8: What an Apple Grower Should Know: Apple Factory System (Pembecioğlu)

In order to have a place in the world markets, it is imperative to obtain varieties suitable for the demands of the market and high-quality marketable products. The varieties that dominate the world market today; Fuji, Gala, Granny Smith, Scarlet Spur, Starkspur Golden Delicious, Starkrimson Delicious, Golden Reinders, Pink Lady, Modi, etc. are known types. With the contracted production of the world's club apple varieties such as Modi, apple exports abroad can be increased.

Regarding the knowledge of the future apple growers, an apple factory system could be implemented. In such a system, everything is evaluated from the very beginning and there may be no chance for failure.

\begin{tabular}{|c|c|c|c|}
\hline \multirow[t]{2}{*}{ Elicitation Stage } & Presentation & Communication \& & Feedback \& Bettermer \\
\hline & Who are the final users & Marketing Strategies & Process \\
\hline Which land / soil & Education & & \\
\hline $\begin{array}{l}\text { Which geography } \\
\text { What Kind of apples }\end{array}$ & $\begin{array}{l}\text { Socio-Economic Status } \\
\text { Cultural Background }\end{array}$ & $\begin{array}{l}\text { Which land / soil } \\
\text { Which geography }\end{array}$ & $\begin{array}{l}\text { Research Based Approach } \\
\text { Who are the final users \& how they react }\end{array}$ \\
\hline - Decision making for the & - Decision making for & What Kind of apples & Main factors of reaction \\
\hline substructure & communication and marketing & - Decision making for the & - Assessing Immediate Impact \\
\hline - IoT Applications & strategy & substructure & - Assessing Delayed Impact \\
\hline - Production and Marketing & $\begin{array}{l}\text { - Accessability } \\
\text { - Availability }\end{array}$ & - IOT Applications & - Reliability \\
\hline Strategies Simultaneously & $\begin{array}{l}\text { - Avallability } \\
\text { - Informativity }\end{array}$ & - Production and Marketing & - Reputation Management \\
\hline - Research and Analysis & - Intentionality (Fresh / Cooking & $\begin{array}{l}\text { Strategies Simultaneously } \\
\text { - Research and Analysis }\end{array}$ & - Target Audience \\
\hline - Betterment of the product & - Respectability & - Research and Analysis & - Passerby \\
\hline & - Intertextuality (Video Films, & & $\begin{array}{l}\text { - Conscious Consumer } \\
\text { - Selective Consumer }\end{array}$ \\
\hline & - Transmedia Facilities & & $\begin{array}{l}\text { - Managing / Leading Consumer } \\
\text { - Loyalty \& Dedication }\end{array}$ \\
\hline
\end{tabular}

Figure 9: Possible integrated skills to be implemented into the Apple Factory System (Pembecioğlu) involving Elicitation, Presentation, Practice, Production and Feedback Sessions 


\begin{tabular}{|c|c|}
\hline $\begin{array}{l}\text { Wholesalers \& } \\
\text { Country Markets }\end{array}$ & Sales \& Marketing \\
\hline Which countries / Why? & Research Based Approach \\
\hline Cost effective strategies & $\begin{array}{l}\text { Who are the final users \& how they react } \\
\text { Main factors of positive/negative reaction }\end{array}$ \\
\hline - Cost effective analysis & - Decision Making on the Market \\
\hline - Cost effective innovation & Value \\
\hline $\begin{array}{l}\text { - Collaborations } \\
\cdot \text { In Turkey } \\
\text { • In Abroad }\end{array}$ & $\begin{array}{l}\text { - Which generation } X, Y, Z \text { ? } \\
\text { - Different appeals \& Dynamics } \\
\text { - Where to Sell - Pricing }\end{array}$ \\
\hline $\begin{array}{l}\text { - Membership to the Unions } \\
\text { - Quality guarantee \& Fame }\end{array}$ & $\begin{array}{l}\text { - Individualized } \\
\text { - Tastes } \\
\text { - Prices } \\
\text { - Amounts } \\
\text { - Accessibility (Vending Machine \& } \\
\text { Special Delivery) }\end{array}$ \\
\hline
\end{tabular}

Figure 10: Being informed about all the possibilities would enrich the knowledge of the farmers

That kind of system in future learning projects would help the farmers, the country, and the economy to get better crops. The media literacy level of the farmers should be increased to follow the new technology, news, and they make use of social media to help their growing businesses. There is also a crucial need for the media people to concentrate on the news regarding such sensitive issues. The fake news or the maximized impact of the news could have a negative side on the farmers dealing with similar products and they may just give up the expectations and experiences of many years. The amount of such discouraging news should be decreased and better role models should be implemented into the news to encourage people for the betterment of their products.

Furthermore, in media, there seems to be no sign of smart agriculture or precision agriculture which are both presenting practical solutions to the traditional farmers. Media should also guide the people minimizing the negative impact of the bad examples and maximizing the level of current technical information to help the development of the farmers.

We need better farmers for better products. And for better farmers, we need better media. Sustainable development and assessment of the products are cruel. A controlled and enhancing process should be maintained. There should be a kind of process-oriented approach instead of a product-oriented approach. In this process, the current methodology of future learning possibilities should be involved. These means would help the farmers, apple growers to reach better-established communities of support to deliver experience, knowledge, and research to each other. There might be farming classes teaching each other how to do things and how to solve problems. In the same sector, people could reach each other via social accounts and/or have better group communication to develop new marketing styles for their future product. Thus, perhaps, they might be able to get some more information and handle the case in an interdisciplinary way as to include information about the other fields such as economy, sociology, marketing, etc. The more they begin to learn about the other goods' prices, the 
income level of the people, their pleasures and preferences, they will better estimate the number of their consumers and understand their expectations. They could also detect if they have any other substitute goods for Apple? Who is demanding: the individuals, groups, society, or the market \& country policies? Who is the target customer? What kind of social status do they represent?

Regarding the conditions of the competition, the apple growers will understand that there is an infinite number of buyers and sellers. Yet, the goods produced by the companies are homogeneous. In perfect competition, buyers and sellers have complete knowledge of the market. If they lack it, they fail. Buyers and sellers behave rationally to maximize their interests. But entry and exit to the market are free. So, the people growing apples should create somewhat unique. This might be a shape differentiation, quality differentiation, prize, taste, colour differentiation, or a kind of regional differentiation.

Good News 1: Malus communis L., local cultivar is known Piraziz Apple by the local people, grown in Piraziz (Giresun). This cultivar was patented by the Turkish Patent and Trademark Office (No: 204 Patent' s Owner: Piraziz Ziraat Odası). Plants have been used by people against various diseases as protective and therapeutic over years (Yeğin, et. al., (2018). Three of the colours yellow, green, and red are seen on an apple. It is an apple variety especially sought after by diabetics. "Piraziz apple" is a local rare product of our country exported from Giresun Port to Egypt and Syria between 1936-1947. It was marketed to fruit juice producers in Tokat and Bursa between 1975-1985 (https://www.hurriyet.com.tr/piraziz-elmasi-tescillendi-40373012).

Good News 2: A harvest activity was organized by the Provincial Directorate of Agriculture and Forestry in the apple garden of Elazig Modern Agriculture (EMT) enterprise in Bulutlu Village, approximately one thousand tons of apples are expected to be harvested from the orchard with 92 thousand trees on 250 thousand square meters. The apple production of the area reaches up to 16 thousand 400 decares and adding into that a closed apple orchard of an area of 611 decares gained support with the certified saplings in the last 10 years (https://www.guneydoguekspres.com/ekonomi/kirmizielma-hasadi-h14423.html).

Good News 3: There's an application in the Turkish culture, "free bread within public reach for the poor" which could be translated as "bread on a hanger" or "suspended bread", or "bread on the hook". Now, after bread and coffee versions, it's time for the apple version generated in Gümüşhane, the land of apple country. Disseminating the idea through social media the city became the center of attention and received appreciation from the citizens (http://www.haberalp.com/guncel/elma-diyari-gumushanede-askida-elmauygulamasi-ses-getirdi-h89375.html).

Making up a mission and vision is necessary for the upcoming Apple Wars. The only way to win the competitions is to digitalize the apple and keeping the mystic part in an internalized way. Thus, researchers and innovators must be able to work and cooperate across the country and EU on a digital platform, questioning, analyzing, and producing altogether. There may be times of scarcity, defined or undefined constraints, however, the budget issues, the reforms, the supply and demand issues as well as growing better products. We have to cope up with them all. 
It is beneficial to dismantle old and small gardens that are out of date and modernize them with new varieties and systems for export, and to establish the new gardens with certified, spur varieties and dwarf or semi-dwarf clon rootstocks. In these gardens, planting systems and cultural maintenance procedures should be applied correctly and without residue and harvested at the right time.

Climate change affects our country as well as the world. Therefore, many of our local varieties, which are resistant to biotic and abiotic stress conditions that may arise, have high fruit quality, and have a very long storage period, should be taken under protection and evaluated in breeding studies.

Our fresh fruit sales are mostly made to Eastern European countries, especially to Russia. Our competitor in apple is Poland, and in order to enter this market, the export opportunity can be increased by growing the Granny Smith, Pink Lady, Fuji, and Red Delicious Group apple varieties that make up $60 \%$ of the world market, which Poland cannot grow due to climate and diseases.

For quality fruit preservation, the number and capacity of mechanical cooling and controlled atmosphere storages should be increased, assuming that our country has a capacity of 2-2.5 million tons, including the warehouses in Nevşehir, and our apple production alone is over 3.5 million tons, at least 6 million tons. It is extremely important to evaluate the products to a capacity.

Producers, public and private sector publishers and consultants, pruners, and warehouse managers should receive in-service training on capping and modern garden establishment, management, and post-harvest storage for quality fruit production and high yield.

As a solution to one of the most problems in our country, it is the establishment of public and private sector breeding parcels that provide certified, virus-free material to its name in accordance with EPPO norms. Failure to achieve standardization with the fruits of different types produced under the name of Eşme, due to the lack of pen breeders in the nurseries, creates an important problem in marketing.

A cold chain system should be established from production to consumption, the capacity of cold storage where advanced preservation techniques can be applied should be increased and expanded, and standardization and packaging in the product should be modernized.

Producer unions and cooperatives should be formed to increase the chance of evaluating and marketing the product. Due to the high input prices in the production, storage, and marketing stages, the amount of credit and support should be increased in order to increase the competition chance.

R\&D activities (in the fields of variety and rootstock breeding, breeding and preservation techniques, etc.) should be developed.

Certified models in production (organic agriculture, ITU, Global GAP) should be widespread for ease of marketing in export and public health in domestic consumption. The number of residue analysis laboratories should be increased across the country, geographic marking, branding, promotion, etc. activities should be given importance. 
The best quality apples do not have any chance in Turkey since we still have to fight with Karaleke and Blackworm as the most common diseases and pests in apples. Intense and unconscious pesticide use is a common problem in apple production. The annual average number of spraying reaches 15. Excessive pesticide use has also brought the problem of resistance. Very successful results are obtained against Apple worm, which is the main pest of apple, with biological control based integrated control activities. The annual number of spraying has been reduced from 15 to 8 through biological control-based integrated combat activities. Efforts should be made to popularize all alternative methods of chemical control, including biological control, in apple production. The time devoted and the amount spent on growing the apple it should meet the price, yet, this could only be possible with the digitalization of the farmers, apple growers as well.

As the results put forward, growing apples require valuing them. It also requires better-established facts, better-trained people, and concentrating more on the specific needs of employees, customers, suppliers, etc.

The purpose of the paper is to pave the way and raise awareness for smart agriculture and to provide the Apple case as an example. The ordinary apple is digitalized as a metaphor for the betterment of energy and dedication. Today's farmers, should become a part of the network, enrich their cultivation methodology and innovation capacities to reach precision agriculture substructure and techniques. Thus, they will be able to understand that the demand function is fluctuating, and they would prevent themselves from a big failure. Actually, growing better apples could only be possible with great care and knowledge. If only this could be achieved, then, the apple wouldn't be a sign of mere physical needs, hunger, etc, but it would be a real crystal apple for each farmer growing it. These needs are often referred to as "gaps," or the difference between what is currently done and what should be performed. So, re-valuing apples require bridging the gap between the mystic apples and the digital apples of the 21st century.

\section{References}

Celik, F., Kazankaya, A., \& Ercisli, S. (2009). Fruit characteristics of some selected promising rose hip (Rosa spp.) genotypes from Van region of Turkey. African Journal of Agricultural Research, 4(3), 236-240.

Cennet, Oğuz \& Karaçayır, H. F. (2009). Türkiye'de elma üretimi, tüketimi, pazar yapısı ve diş ticareti. International Journal of Agricultural and Natural Sciences, 2(1), 4149.Celik, F., Kazankaya, A., \& Ercisli, S. (2009). Fruit characteristics of some selected promising rose hip (Rosa spp.) genotypes from Van region of Turkey. African Journal of Agricultural Research, 4(3), 236-240.

Chatzopoulos, T., Domínguez, I. P., Zampieri, M., \& Toreti, A. (2020). Climate extremes and agricultural commodity markets: a global economic analysis of regionally simulated events. Weather and Climate Extremes, 27, 100193. 
Çolak, A. M., \& Özoğul, A. (2020). Pomological and Biochemical Characteristics of Local Apple Genotypes Grown in Uşak-Turkey. Pak. J. Bot, 52(3), 955-961.

Dursunoglu, S., \& Ertunc, F. (2006, May). Distribution of Apple mosaic ilarvirus (ApMV) in Turkey. In XX International Symposium on Virus and Virus-Like Diseases of Temperate Fruit Crops-Fruit Tree Diseases 781 (pp. 131-134).

Dündar, O., Uygun, I., \& Ozkaya, O. (2009, April). Cold storage of' Granny Smith' apples that were grown in Nigde-Turkey conditions. In $X$ International Controlled and Modified Atmosphere Research Conference 876 (pp. 355-359).

Ellenwood, C. W. (1930). The cost of developing an apple orchard.

Emongor, V. E., \& Murr, D. P. (2001). Effect of Benzyladenine on Fruit Set, Quality, and Vegetative Growth of 'Empire' Apples. East African Agricultural and Forestry Journal, 67(1-2), 83-91.

Engindeniz, S., Cukur, F., \& Engindeniz, D. Y. (2003). Alternative opportunities for small farms: A case study on technical and economic analysis of peach growing in Turkey. Journal of agricultural $\mathcal{E}$ food information, 5(4), 47-58.

Erkan, M., Pekmezci, M., Gübbük, H., \& Karaşahin, I. (2004). Effects of controlled atmosphere storage on scald development and postharvest physiology of Granny Smith apples. Turkish Journal of Agriculture and Forestry, 28(1), 43-48.

Food Agricultural Organization, 2006

Gül, M. (2006). Technical efficiency of apple farming in Turkey: A case study covering Isparta, Karaman and Nigde provinces. Pakistan Journal of Biological Sciences, 9(4), 601-605.

http://www.haberalp.com/guncel/elma-diyari-gumushanede-askida-elma-uygulamasises-getirdi-h89375.html Accessed in 11.11.2020.

http://www.isteisparta.com/newsdetails.asp?id=952 Accessed in 11.11.2020.

http://www.wapa-association.org/asp/page 1.asp?doc id=436 Accessed in 11.11.2020. http://www.wapa-association.org/asp/page members.asp Accessed in 11.11.2020. https://apps.fas.usda.gov/psdonline/circulars/fruit.pdf Accessed in 11.11.2020. https:/ec.europa.eu/info/sites/info/files/food-farming-

fisheries/farming/documents/apples-production en.pdf Accessed in 11.11.2020.

https://ec.europa.eu/research/innovation-union/pdf/innovation-union-

communication en.pdf Accessed in 11.11.2020.

https://en.wikipedia.org/wiki/List of countries by apple production Accessed in 11.11.2020.

https://tarimdabugun.wordpress.com/2015/12/19/turkiyede-elma-uretimi// Accessed in 11.11.2020.

https://www.aa.com.tr/tr/turkiye/kagizman-uzun-elmasi-tescillendi/1030059 Accessed in 11.11.2020.

https://www.appleawards.com/crystal-apples-awards/ Accessed in 11.11.2020. https://www.dailymail.co.uk/news/article-2449221/Stroud-apple-tree-Eco-warrior-

Rowan-Burrough-living-tree-homes-built.html Accessed in 11.11.2020.

https://www.fruitlogistica.com/media/fl/fl dl all/auf einen blick/European Statistics Handbook 2020.pdf Accessed in 11.11.2020. 
https://www.guneydoguekspres.com/ekonomi/kirmizi-elma-hasadi-h14423.html

Accessed in 11.11.2020.

https://www.hurriyet.com.tr/bilincsiz-tarim-politikalari-meyve-suyu-sektorune-zararveriyor-12794885 Accessed in 11.11.2020.

https://www.hurriyet.com.tr/ekonomi/50-bin-ton-elma-depoda-kaldi-40085193

Accessed in 11.11.2020.

https://www.hurriyet.com.tr/ekonomi/bodur-elma-uretiminde-buyuk-artis-16489399

Accessed in 11.11.2020.

https://www.hurriyet.com.tr/ekonomi/ciftciler-iklim-degisikligi-ve-kuraklikla-

mucadeleyi-ogreniyor-41608821 Accessed in 11.11.2020.

https://www.hurriyet.com.tr/ekonomi/deveci-armutlari-depolarda-kaldi-fiyatlar-dipte22917916 Accessed in 11.11.2020.

https://www.hurriyet.com.tr/ekonomi/elma-cipsi-ic-piyasada-14811254 Accessed in

11.11.2020.

https:/www.hurriyet.com.tr/ekonomi/hem-siginmacilari-hem-ureticileri-sevindiren-

yardim-28415856 Accessed in 11.11.2020.

https:/www.hurriyet.com.tr/ekonomi/ispanakla-portakal-kis-in-en-sevilen-i-cikti-ayva-

ile-karalahana-dipte-kaldi-19202378 Accessed in 11.11.2020.

https://www.hurriyet.com.tr/ekonomi/tarim/bugday-ve-kayisi-uzdu-cay-ve-uzum-

guldurdu-27840323 Accessed in 11.11.2020.

https://www.hurriyet.com.tr/ekonomi/yas-sebze-ve-meyve-ihracatinda-pandemi-

surecinde-artis-41588840 Accessed in 11.11.2020.

https://www.hurriyet.com.tr/ekonomi/yerel-meyvenin-suyu-cikti-27199849 Accessed in 11.11.2020.

https://www.hurriyet.com.tr/ekstra-ozel/lezzet/mitolojide-de-yeri-var-gunumuz-

sofrasinda-da-elmanin-hic-bilmediginiz-ozellikleri-41602971 Accessed in

11.11.2020.

https://www.hurriyet.com.tr/elmayi-bu-sistem-koruyacak-26224543 Accessed in

11.11.2020.

https://www.hurriyet.com.tr/isparta-da-elma-hasadi-basladi-37177858 Accessed in

11.11.2020.

https://www.hurriyet.com.tr/ispartaya-kiraz-ve-elma-heykelleri-40298664 Accessed in 11.11.2020.

https://www.hurriyet.com.tr/kaliteli-elma-pazar-bulamiyor-21666972 Accessed in 11.11.2020.

https://www.hurriyet.com.tr/kelebek/elma-sirkesi-mucizesi-14982987 Accessed in 11.11.2020.

https://www.hurriyet.com.tr/kelebek/havva-da-adem-i-boyle-kandirmisti-diye-

sevgilisine-elma-gonderen-var-17313132 Accessed in 11.11.2020.

https://www.hurriyet.com.tr/kelebek/iste-kanserden-koruyan-yiyecekler-12740022

Accessed in 11.11.2020.

https://www.hurriyet.com.tr/kelebek/keyif/kacak-kazida-ortaya-cikan-1800-yillik-elmamozaigi-sergileniyor-41568471 Accessed in 11.11.2020. 
https://www.hurriyet.com.tr/kesilen-agacini-omuzladi-neden-kestiniz-diye-40519706 Accessed in 11.11.2020.

https://www.hurriyet.com.tr/korkutelide-elma-ihracati-40355797 Accessed in 11.11.2020. https://www.hurriyet.com.tr/lezizz/dolapta-5-gun-dayanabiliyor-soydugunuz-elmalarartik-renk-degistirmeyecek-41618911 Accessed in 11.11.2020.

https://www.hurriyet.com.tr/lezizz/galeri-ici-disi-kirmizi-elmaya-cografi-isaret-tescili41340564 Accessed in 11.11.2020.

https://www.hurriyet.com.tr/lezizz/kaliteli-uykunun-yolu-da-mutfaktan-geciyor41599606 Accessed in 11.11.2020.

https://www.hurriyet.com.tr/mahmure/menopozda-saglikli-beslenme-tuyolari$\underline{41605315}$ Accessed in 11.11.2020.

https://www.hurriyet.com.tr/piraziz-elmasi-tescillendi-40373012 Access 11.11.2020 https://www.hurriyet.com.tr/uretim-yuzde-116-artti-21791926 Access 11.11.2020 https://www.indexmundi.com/agriculture/?commodity=apples\&graph=production Accessed in 11.11.2020.

https://www.lithgowmercury.com.au/story/184990/the-history-of-the-granny-smithapple/ Accessed in 11.11.2020.

https://www.mevka.org.tr/Yukleme/Uploads/Dsytc6Ix5719201754304PM.pdf Accessed in 11.11.2020.

https://www.youtube.com/watch?v=581Kx8wzTMc Accessed in 11.11.2020. https://www.youtube.com/watch?v=AavSPaDPjC4 Accessed in 11.11.2020. https://www.youtube.com/watch?v=AavSPaDPjC4 Accessed in 11.11.2020. https://www.youtube.com/watch?v=RQvyicE0ByI Accessed in 11.11.2020.

https://www.zmo.org.tr/genel/bizden detay.php?kod=32410\&tipi=38\&sube=0 Accessed in 11.11.2020.

J. P. Shi (2010). Characteristics of apple consumption demand in China, Northwest Agriculture and Forestry University (in Chinese).

Janick, J. (2005). The origins of fruits, fruit growing, and fruit breeding. Plant breeding reviews, 25, 255-320.

Karabati, S., Dogan, E., Pinar, M., \& Celik, L. M. (2009). Socio-economic effects of agritourism on local communities in Turkey: The case of Aglasun. International Journal of Hospitality \& Tourism Administration, 10(2), 129-142.

Karadeniz, F., Burdurlu, H. S., Koca, N., \& Soyer, Y. (2005). Antioxidant activity of selected fruits and vegetables grown in Turkey. Turkish Journal of Agriculture and Forestry, 29(4), 297-303.

Khan, M., \& Bae, J. H. (2017). The environmental perspectives of apple fruit supply Chain management in Chitral, Northern Pakistan. International Journal of Supply Chain Management, 6(4), 1-16.

Küden, A., Küden, A. B., İmrak, B., \& Sarier, A. (2016, October). Apple growing in Turkey. In I International Apple Symposium 1261 (pp. 25-28).

McKenna, M., Le Heron, R., \& Roche, M. (2001). Living local, growing global: Renegotiating the export production regime in New Zealand's pipfruit sector. Geoforum, 32(2), 157-166. 
Memon, N. A. (2014) Apple is a symbol of health. Pakistan Food Journal, p. 34-36, October-November-2014. Available from: http://foodjournal.pk Access 11.11.2020

Merwin, I. (2008). Some antique apples for modern orchards. New York Fruit Quart, 16, 11-17.

Oğuz, C., Karakayac1, Z., \& Kalyoncu, İ. H. (2009). Apple Production and Marketing in Turkey. In International Symposium on Sustainable Development (ISSD), June (pp. 9-10).

Okcu, M., Kalkışım, Ö., Okcu, Z., Karabulut, B., Yildirim, N., \& Agar, G. (2015). Determination of genetic diversity among wild grown apples from eastern black sea region in Turkey using ISSR and RAPDs markers. Erwerbs-Obstbau, 57(4), 171-177.

Ozrenk, K., Balta, F., Guleryuz, M., \& Kan, T. (2011). Fire blight (Erwinia amylovora) resistant/susceptibility of native apple germplasm from eastern Turkey. Crop Protection, 30(5), 526-530.

Pirlak, L., Güleryüz, M., Aslantaş, R., \& Eşitken, A. (2003). Promising native summer apple (Malus domestica) cultivars from north-eastern Anatolia, Turkey. New Zealand Journal of Crop and Horticultural Science, 31(4), 311-314.

Pirog, R. S., \& Tyndall, J. C. (1999). Comparing apples to apples: An Iowa perspective on apples and local food systems.

TC Kalkınma Bakanlığı'nın hazırlamış olduğu Onuncu Kalkınma Planı, Bitkisel Üretim Özel İhtisas raporu 2014-2018.

Topcu, Y., Uzundumlu, A. S., Celep, S., \& Hun, S. (2010). Analysis of the factors affecting apple farming: The case of Isparta province, Turkey. Scientific Research and Essays, 5(14), 1881-1889.

Uzunöz, M., \& Akcay, Y. (2006). A profitability analysis of investment of peach and apple growing in Turkey. Journal of Agriculture and Rural Development in the Tropics and Subtropics (JARTS), 107(1), 11-18.

Yeğin, S. Ç., Güder, A., Kılıç, A., \& Aydın, H. (2018) Yeni Elma Kültürü: Piraziz Elmasının (Malus communis L.) Antioksidan İçeriğinin ve Antidiyabetik Etkisinin Araştırılması. Ĭğdır Üniversitesi Fen Bilimleri Enstitüsü Dergisi, 8(3), 237-242.

Yue, C., Jensen, H. H., Mueller, D. S., Nonnecke, G. R., Bonnet, D., \& Gleason, M. L. (2007). Estimating consumers' valuation of organic and cosmetically damaged apples. HortScience, 42(6), 1366-1371.

Zhao, X., Han, M., Deng, Q., \& Xue, K. (2019, July). Decisions on supply and demand of bicycle-sharing service based on cobweb model. In 2019 16th International Conference on Service Systems and Service Management (ICSSSM) (pp. 1-5). IEEE. 
Nilüfer Pembecioğlu, Nebahat Akgün Çomak

VALUING APPLES: FROM THE MYSTIC APPLE TO THE DIGITAL APPLES OF THE 21st CENTURY

Creative Commons licensing terms

Authors will retain copyright to their published articles agreeing that a Creative Commons Attribution 4.0 International License (CC BY 4.0) terms will be applied to their work. Under the terms of this license, no permission is required from the author(s) or publisher for members of the community to copy, distribute, transmit or adapt the article content, providing a proper, prominent and unambiguous attribution to the authors in a manner that makes clear that the materials are being reused under permission of a Creative Commons License. Views, opinions and conclusions expressed in this research article are views, opinions and conclusions of the author(s). Open Access Publishing Group and European Journal of Economic and Financial Research shall not be responsible or answerable for any loss, damage or liability caused in relation to/arising out of conflict of interests, copyright violations and inappropriate or inaccurate use of any kind content related or integrated on the research work. All the published works are meeting the Open Access Publishing requirements and can be freely accessed, shared, modified, distributed and used in educational, commercial and non-commercial purposes under a Creative Commons Attribution 4.0 International License (CC BY 4.0). 